\title{
Free trade agreements in Latin America since 1990: an evaluation of export diversification
}

\author{
Alfonso Dingemans and César Ross
}

ABSTRACT

This article explores the previously uncontested claim that the free trade agreements (FTAS) signed by Latin American countries - the cornerstone of their international economic integration strategies since 1990- have led to export diversification in terms of variety of goods and number of trading partners. Using data from the United Nations Commodity Trade Statistics Database (COMTRADE), we show that the bulk of export growth in the region has been in the intensive rather than the extensive margin. Concentration indices support the finding that the expansion of exports into new products and new trading partners has been limited. Latin America's bid to diversify its exports using FTAs (based on a static concept of comparative advantages) instead of more comprehensive strategies has had a negligible impact. Governments should therefore adopt a more dynamic approach to comparative advantages and introduce more active policies. Finally, we pose some open questions for future research. alfonso.dingemans@usach.cl

César Ross, Institute for Advanced Studies (IDEA), Universidad de Santiago de Chile. cesar.ross@usach.cl 


\section{I}

\section{Introduction}

Although the Latin American economies ${ }^{1}$ were skeptical about the advantages and benefits of (free) trade during the belle époque (1940-1975), the devastating debt crisis of the 1980s forced the previously neglected export sector into the limelight. Countries urgently needed foreign currency to pay off their enormous debts, and their economic survival was thus determined primarily by their export capacity (Edwards, 1995; Ffrench-Davis, Muñoz and Palma, 1996; Thorp, 1998; Bulmer-Thomas, 2003).

For many reasons, a nominally pro-market economic reform package of 10 measures proposed and used by various Washington-based institutions - referred to as the Washington Consensus (Williamson, 1990) — was widely adopted in Latin America, although some scholars question to what extent the reforms implemented were actually pro-market (Edwards, 2010). The Consensus promoted the idea of free trade and stressed the need for a sound export sector, with opening up to international competition put forward as the only way to weed out inefficient firms. It was supposed that boosting the export sector would have important trickle-down effects for the rest of the economy (an idea present in Adam Smith's work) because of which it was thought that export growth (maximized under free trade) and economic growth were closely tied. However, research has shown that free trade alone is not enough and can even be detrimental to economic growth (Taylor, 1991; Rodríguez and Rodrik, 1999; Van den Berg and Lewer, 2007; Mejía, 2011). Instead, governments should take a more active stance by "influencing the type and sequencing of exports, as a country strives to produce more advanced products, adding higher value" (Todaro and Smith, 2006, p. 441).

This means that, in order for the causal chain of free trade, export growth, economic growth and economic

\footnotetext{
$\square$ We would like to express our appreciation for the helpful comments of an anonymous referee. We gratefully acknowledge the financial support received from the post-doctoral fellowship of the Programme on Improving the Quality and Equity of Higher Education (MECESUP UCH0602) of the Doctorate in American Studies at the Universidad de Santiago de Chile. All errors and omissions are our own.

1 In this article, we are referring to the 11 largest economies in terms of gross domestic product (GDP): Argentina, Bolivarian Republic of Venezuela, Brazil, Chile, Colombia, Ecuador, Mexico, Paraguay, Peru, Plurinational State of Bolivia and Uruguay.
}

development ${ }^{2}$ to work, an economy must export more value added goods, which can be achieved only through active government policies. Thus, countries should shift the emphasis of their international economic positioning strategy from a traditional, Ricardian (static or passive) approach to comparative advantages - which occur unintentionally - to a more dynamic strategy where active government or industrial policies are implemented to bring about the structural change required to generate intentional comparative advantages, though without disregarding free trade entirely (Agosín, 2006, p. 2; Mejía, 2011, p. 36). The Asian experience has shown that trade policies and free trade are not necessarily incompatible and, indeed, can be complementary (Fishlow and others, 1994). To put it another way, what matters for economic development is the quality of export growth.

The diversification of exports, ideally with a shift towards more value added goods, is a good benchmark against which to assess an economy's export performance and "is all the more urgent in today's economic context" (Leipziger, 2009, p. xi). Diversification is understood here as an increased variety of goods exported to a larger number of foreign markets, with a more even distribution between those markets. This last condition is not normally part of the definition of diversification, but we consider it essential since it would be erroneous, for instance, to claim that a country's exports are more diversified when it manages to gain access to 10 new markets if one single foreign market continues to represent $95 \%$ of its total exports.

It may seem surprising to defend the idea of diversification, as opposed to the notion of specialization espoused by standard, classical trade theory; however, three advantages can be identified in favour of diversification (Mejía, 2011): (i) it operates as a hedging strategy, introducing more stability in export earnings; (ii) if other institutional conditions are in place, it can trigger structural change; and (iii) if that structural change succeeds, it can enhance sustained economic growth.

\footnotetext{
2 Economic development is defined here as a "process of structural transformation where countries move from producing 'poor-country goods' to 'rich-country goods'" (Hesse, 2008, p.1) or, in other words, from producing goods with little added value to goods with high added value.
} 
According to Agosín (2006), in the long run, provided that structural change occurs, diversification can lead an economy to reap the benefits of a more diversified specialization. The causal chain we propose therefore is: (free trade,) export growth, export diversification, economic development, economic growth; free trade is a complementary condition, but not a sufficient one.

We must do two things in order to gain an accurate picture of countries' export diversification according to our definition. First, we must differentiate between export growth (Brenton and Newfarmer, 2009, p. 112) in the extensive margin (growth of existing goods to existing markets) and that in the intensive margin (expansion of new goods to existing markets, existing goods to new markets or new products to new markets). Second, in follow-up to the first step, we must compute concentration indices (Samen, 2010).

In spite of the arguments in favour of active government policies, the practice in Latin America has been somewhat different, with governments displaying a marked preference for static comparative advantages. Since the breakdown of the third World Trade Organization Ministerial Conference held in 1999 in Seattle, United States of America, and the standstill of the Doha Round, the countries in Latin America have adopted free trade agreements (FTAs, bilateral or plurilateral trade agreements established under Article XXIV of the General Agreement on Tariffs and Trade (GATT) as exceptions to its mostfavoured-nation provisions) as their prime vehicle of international economic integration.

Their worldwide popularity prompted Bhagwati (1995) to speak, perhaps unfairly, of an "infatuation" with such agreements. As to their many positive effects, FTAS are attributed with lowering tariffs and non-tariff barriers, increasing market access, improving the level of competitiveness, fostering the growth of foreign direct investment (FDI), reducing levels of uncertainty and risk, and creating jobs thanks to higher exports (Lynch, 2010, pp. 2-9). Furthermore, numerous academics and policymakers are optimistic about the impact of FTAs on export diversification, which we shall call the FTA-export diversification nexus.

It would seem, therefore, that FTAs are in fact examples of active policies designed to achieve more diversified exports. This is partly true. When negotiating an FTA, governments are actively pursuing the diversification of exports. But there are two caveats. First, what if FTAs only confirm existing economic ties? Can replacing informal practices with formal practices really be considered an active policy? An FTA is merely the infrastructure for trade. By analogy, when a government builds a bridge, it does not usually use policy to try to influence the type of people who use the bridge. Similarly, many Latin American governments, believing that their job is done once an FTA (the bridge) has been signed, do not pay attention to the kind of goods their countries subsequently export. This approach is in keeping with orthodox policymaking, where the government provides the basic infrastructure and the private sector determines when and how to use it (within legal bounds, obviously). The idea that FTAs can singlehandedly bring about export diversification is in line with this philosophy.

In fact, if an FTA-export diversification nexus existed, its impact on prices would be enough to bring about change in the productive structure of an economy and the government's role vis-à-vis economic development would be reduced to supplying an adequate infrastructure and stepping back so as not to interfere in its actual use. In that case, discussions regarding the difference between static and dynamic comparative advantages, and the limits between State and market, would be superfluous. Assessing the impact of FTAS on export diversification is therefore crucial to development, both in theoretical and practical terms. If it were proved that a laissez-faire approach led to economic development, more active industrial policies would not be necessary.

Surprisingly, there are only a handful of investigations addressing this issue, with most research focusing on the nexus between economic growth and export growth (Mejía, 2011; Volpe and Milena, 2009). Hence, the time has come to begin to explore systematically to what extent FTAS have been conducive to export diversification (the quality of export growth) in Latin America in order to determine how governments can or should try to influence export efforts, and subsequently to add to the broader discussion on the limits between the State and the market.

This article therefore aims to contribute to a new research agenda that critically evaluates the economic integration strategies of Latin America in the light of export diversification rather than export growth. Because it is difficult to disentangle and isolate the different causalities at work, the first task is to describe and conduct a preliminary assessment of the impact of FTAS in terms of export diversification given their popularity as a policy tool. We do not intend to oversimplify this issue by reducing it to a single factor; this is merely a first step that will enable us to include other contingent variables, such as terms of trade, at a later stage. Future investigations could examine the (international) politics 
of diversification, that is, how the winners and losers of trade liberalization exert influence in the policymaking process to enhance or thwart diversification; to that end, future case studies could follow a model similar to Mejía (2011). Future research could also focus on alternative pathways to achieving export diversification, for example through foreign direct investment. ${ }^{3}$ Similarly, other instruments used to position Latin America in the global economy, such as export promotion activities, merit further investigation in terms of their impact on export diversification; however, our preliminary findings published elsewhere on this topic are discouraging.

In this article we will restrict ourselves to an exploratory, quantitative assessment of the relationship between FTAS and export performance in terms of diversification using data from the United Nations Commodity Trade Statistics Database (COMTRADE). Our findings show that FTAs have had little effect on the productive structure of the export sector (particularly with regard to its ability to produce new exportable goods) and on its expansion into new markets. FTAs do not create new patterns and structures, but confirm existing ones. This lack of structural change is further confirmed by fairly stable concentration indices.

First, this means that the current optimism regarding the FTA-export diversification nexus is misplaced —and the argument in favour of industrial policies largely correct - since any diversification would be the result of earlier processes, that is, prior to and independent of the signing of FTAs. This is seen most clearly in the case of Chile, where the diversification process took place in the 1970s and 1980s, not in the last 20 years; FTAS have therefore had virtually no effect on the productive structure of Chilean exports. In addition, the effect of FTAS on the creation of new markets has been limited, as will be shown below, since the countries that have signed FTAS already had firm economic ties (they can be considered "natural markets") and these agreements were merely a formal acknowledgement at the State level of existing informal practices. Nevertheless, we cannot unequivocally rule out a link between FTAS and export diversification (the scope and aim of this article are too limited to be able to do that) since the effect of each FTA depends on the signatory parties' "fundamentals" (the conditions each country needs for export diversification to take place) (Hausmann, Hwang and Rodrik, 2007). More case-by-case evidence is therefore needed.

Second, our findings support taking a more moderate stance on the envisaged effects of FTAS. FTAS are no guarantee of high-quality export growth and are not a substitute for industrial and social policies (Malvasio, 2006). In other words, although agreements are a vital piece of the international trade architecture, just because they exist does not necessarily mean that their use will automatically promote diversification. Furthermore, even if FTAs did have a diversifying effect on exports, the question remains as to whether the incentives contained in FTAs would outweigh other, opposing incentives, such as high commodity prices (as in the case of China) that favour commodity exports. In that case a more active industrial policy could mitigate the influence of those other incentives. We hold that the market alone cannot achieve economic development and that industrial policies remain an important tool (Rodrik, 2011; Chang, 2012). Future research should help to identify the best policies or instruments for strengthening the link between the export sector and economic development.

This article is organized into four sections. In section II, we show the importance of exports in the development strategies of Latin American countries, and particularly of FTAS in their international economic integration strategies. In section III, we assess the quality of export growth in our sample of countries; to that end, we set out our methodology and highlight the changes observed in the composition of countries' trading partners and their exports. We then reveal the breakdown of export growth in the extensive and intensive margins. To complete our assessment of the diversification of exports, we provide a summary of four concentration indices (for countries and products). We evaluate to what extent FTAs have been inimical to gaining access to new markets and to fostering change in the productive structure (exporting new products). Lastly, section IV contains our conclusions and a call for further research.

3 Foreign direct investment is an explicit issue of bilateral trade agreements, but it will not be addressed here because it goes beyond the scope of this article. 


\section{II}

\section{Latin America's international economic integration through FTAS}

The 1980s were difficult for Latin America. The region's economies had been on a downward path since the first oil crisis of the early 1970s (if not before). One of the reasons for this was the inward-looking development strategy known as import-substitution industrialization (ISI) - initially adopted by the region in response to the Great Depression - which had introduced an anti-export bias that led to serious difficulties in financing imports of capital goods, which was an essential part of that very development strategy (Ffrench-Davis, Muñoz and Palma, 1996). Furthermore, the excessive expansion of the State (in terms of both its role and its relative weight within the economy), though undoubtedly necessary for social peace, made fiscal equilibrium virtually impossible. The petrodollars and eurodollars that gushed into Latin America's economies turned out to be a siren song, offering temporary relief to these economies in the short run, but failing, in the absence of structural reforms, to ward off collapse since these loans had to be paid back at some point. Worse still, these capital flows were destined for consumption rather than for investment and, given the highly uncompetitive export sector, any sudden increase in the cost of borrowing would make it extremely difficult to honour payments. Indeed, when the interest rate in the United States shot up in June 1982, causing a diversion of capital flows, the Mexican government defaulted. The ensuing financial panic spread to the whole region, leaving it in effect economically moribund.

The orthodox interpretation of the facts blamed Latin America's malaise on an excessive State presence and measures were proposed to unleash market forces under the slogan of "more market and less State" - measures which Williamson (1990) would dub the Washington Consensus. For a plethora of reasons not discussed here (see, for example, Edwards, 1995 and 2010; Yergin and Stanislaw, 1998; Thorp, 1998; Stokes, 2001), in the early 1990s the Latin American countries, with hardly any exceptions, embraced — at least nominally — the policy prescriptions of the Washington Consensus. To what extent the economic reforms of the 1990s can be considered orthodox is under debate, with some scholars questioning whether they can be considered orthodox at all (Edwards, 2010). Nevertheless, governments lowered their tariffs on average, though not necessarily across the board, and opened up their economies to international competition, thus joining the wave of globalization based on a model of static comparative advantages, since industrial policy had become - according to Rodrik (2011) - a taboo.

The results, however, were not always positive. In the absence of mobility-enhancing policies (such as re-education plans) and social safety nets, the deindustrialization resulting from increased competition was followed by structural unemployment and underemployment, precarious social and economic conditions and a growing informal sector. Exports were primarily limited to agricultural and mineral commodities with little added value, technological innovation or sophistication.

The failure of the Washington Consensus to solve Latin America's political, economic and social problems - for it would be unjust to suggest that the reforms introduced these problems to Latin America- eventually led to a backlash in the form of a "left turn" (Castañeda, 2006). The more left-leaning governments that came into office improved, changed or outright replaced several of the reforms. Exports, however, remained the cornerstone of their development strategies, regardless of their antipathy, in some cases, towards orthodox economic thinking. Even Hugo Chávez in the Bolivarian Republic of Venezuela - a champion of anti-capitalism - and the Kirchner and Fernández administrations in Argentina — proponents of more traditional populist economic policies, as defined by Dornbusch and Edwards (1991) — acknowledge the importance of exports.

FTAS would seem to be the best way to enhance export growth, especially in the light of failing World Trade Organization rounds of multilateral negotiations. Even Chávez dreams of a Bolivarian free-trade bloc, albeit exclusively for Latin American nations. The signing of FTAs is heralded by presidents and the media as the quintessential vehicle for promoting free trade, boosting exports and gaining access to and prestige on the global economic and political stage. Such agreements are the cornerstone of Latin America's 
current international economic insertion strategy and it is therefore understandable that governments and scholars tend to have high expectations of them.

Despite the aforementioned "left turn", governments are optimistic (though not complacent) regarding Latin America's export growth performance and specifically regarding the FTA-export diversification nexus. A quick glance at the public debate confirms this idea. For instance, Barbara Weisel, Assistant United States Trade Representative for South-East Asia and the Pacific, said that the FTA between the United States and Malaysia would create new opportunities and support Malaysia's goal of diversifying its exports and boosting value-added trade (Bernama, 2007). When asked to comment on the future FTA between China and Peru, economist Michael Pettis of Peking University said that the current situation in China's economy, which is shifting towards manufactures imports, would drive Peru to diversify its exports (La Primera, 2012). According to a report by a private consultancy firm, over the long term, there is little doubt that the FTA between China and the Association of Southeast Asian Nations (ASEAN) will help improve export diversification (BMI View, 2010). In a joint statement by President Obama and President Piñera on the occasion of President Obama's visit to Chile, they underscored that in the seven years since the United States-Chile FTA had entered into force, not only had the conditions of exchange of goods and services improved, but also new business opportunities had been created, leading to the diversification of products (Ministry of Foreign Affairs of Chile, 2011). In a book published by the General Directorate for International Economic Affairs of Chile 4 to mark 20 years of Chile's experience in trade negotiations, the authors conclude that in the period 1990-2010 there has been considerable diversification in the goods the country exports and its trading partners (DIRECON, 2010, p. 11). Finally, on a more theoretical level, Volpe and Milena (2009, pp. 4-5) talk of an emerging consensus in the specialized literature on the linkage between tariff levels and an economy's ability to export new products, with most countries applying a Ricardian model that predicts that "a reduction in trade barriers leads to an increased range of exported goods".

If half of these perceptions were true, the popularity of FTAs would not be surprising, but the problem

4 The responsibilities of the General Directorate for International Economic Affairs (DIRECON), part of the Ministry of Foreign Affairs of Chile, include planning and executing Chile's economic foreign policy and negotiating FTAs. (potentially, at least) is that these claims are not backed by evidence. We should therefore assess whether FTAS are truly conducive to export diversification or whether this is rather a case of "much ado about nothing". In this article we will try to come to a preliminary answer and suggest areas for future research that may be able to deliver a more in-depth analysis.

First, are FTAs indeed so popular? As at January 2012, the $\mathrm{WTO}^{5}$ had received some 511 notifications of regional trade agreements, $90 \%$ of which corresponded to FTAS and partial trade agreements (PTAS). Of these, some 319 agreements were in force. According to the Foreign Trade Information System of the Organization of American States, ${ }^{6}$ there are 64 FTAs, 3 framework agreements and 33 PTAS in force among its member States, which are summarized in table 1.7

Chile and Mexico have signed the most FTAs, while the Bolivarian Republic of Venezuela and Colombia account for over $50 \%$ of all the PTAs signed (see table 1). All of the PTAs signed by the countries in Latin America are with partner countries in South and Central America, whereas some of the FTAS are of an intercontinental nature. Traditional trade partners in Latin America, North America and Europe 8 account for roughly $60 \%$ of all the agreements signed and non-traditional partners in Asia and Oceania account for $30 \%$. This suggests that FTAS are used in Latin America to confirm or deepen existing trade ties, rather than to establish new ones.

Colombia, Mexico and above all Chile have signed the most FTAs with countries from other continents. At the other end of the scale, the Bolivarian Republic of Venezuela has signed only PTAs.

Latin American countries have shown an increasing preference for FTAs over PTAs. In fact, the last PTA was signed in the region in 2004. To date, Latin American countries or trading blocs have signed 39 FTAs against 29 PTAs. In comparison, before 1997, less than 25\% of all trade agreements signed by Latin American countries were FTAs. This suggests that Latin American countries are seeking ever broader economic integration;

\footnotetext{
5 See [online] http://www.wto.org/english/tratop_e/region_e/ region_e.htm.

6 See [online] http://www.sice.oas.org/agreements_e.asp.

7 The FTAS and PTAS signed by the members of the Southern Common Market (MERCOSUR) are included for each of the relevant States: thus, the four FTAS signed by MERCOSUR account for a total of 16 FTAS in the table (four for each member) and the one PTA signed by the trading bloc is counted four times (once for each member).

8 The two FTAs signed by Chile and Mexico with the European Union are counted as two FTAS and not as 27 separate agreements with each 27 European Union member States.
} 
nonetheless, traces of protectionism remain, as can be seen, for example, in the latest measures implemented by President Fernández in Argentina.

In sum, FTAs appear to be an increasingly important instrument for achieving economic integration; however, the geographical distribution of FTA trading partners is less than satisfactory, since such agreements are signed mainly with the region's traditional partners, thus merely formalizing existing ties with natural markets rather than creating new ones. In addition, in line with the philosophy underpinning the Washington Consensus, FTAs are seen as an end in themselves, rather than as an element of a more encompassing, active trade policy that would seek to foster the export of more value added products. Countries are therefore currently employing a strategy built around static comparative advantages. These points will be addressed more thoroughly in the next sections.

TABLE 1

Latin America (selected countries): signed trade agreements in force by number of agreements and number of trading partners

\begin{tabular}{|c|c|c|c|c|c|c|}
\hline Country & $\begin{array}{c}\text { Free trade } \\
\text { agreements } \\
\text { (simple count) }\end{array}$ & $\begin{array}{l}\text { Partial trade } \\
\text { agreements } \\
\text { (simple count) }\end{array}$ & $\begin{array}{l}\text { Total number of } \\
\text { treaties }\end{array}$ & $\begin{array}{c}\text { Free trade } \\
\text { agreements } \\
\text { (country count) }\end{array}$ & $\begin{array}{l}\text { Partial trade } \\
\text { agreements } \\
\text { (country count) }\end{array}$ & $\begin{array}{l}\text { Total number of } \\
\text { trading partners }\end{array}$ \\
\hline Argentina & 4 & 6 & 10 & 4 & 8 & 12 \\
\hline Bolivia (Plur. State of) & 2 & 1 & 3 & 5 & 1 & 6 \\
\hline Brazil & 4 & 5 & 9 & 4 & 7 & 11 \\
\hline Chile & 16 & 4 & 20 & 52 & 4 & 56 \\
\hline Colombia & 5 & 6 & 11 & 10 & 25 & 35 \\
\hline Ecuador & 0 & 4 & 4 & 0 & 7 & 7 \\
\hline Mexico & 13 & 4 & 17 & 44 & 6 & 50 \\
\hline Paraguay & 4 & 3 & 7 & 4 & 5 & 9 \\
\hline Peru & 10 & 1 & 11 & 14 & 1 & 15 \\
\hline Uruguay & 5 & 4 & 9 & 5 & 6 & 11 \\
\hline Venezuela (Bol. Rep. of) & 0 & 10 & 10 & 0 & 29 & 29 \\
\hline
\end{tabular}

Source: Foreign Trade Information System, Organization of American States (OAS) [online] http://www.sice.oas.org, January 2012.

\section{III}

\section{Latin American export growth: diversification or concentration?}

Having discussed the importance and characteristics of the trade agreements (FTAs and PTAs) adopted as part of Latin America's international economic integration strategies, in this section we will analyse the results of that strategy by looking at three areas. First, we will present a detailed analysis of Latin America's export growth in both the extensive and intensive margins. Then we will assess whether Latin American countries have shown a tendency towards diversification or concentration in terms of their trading partners and the products exported. Third, we will investigate whether FTAs have had any significant effect on that process of diversification or concentration. But before answering these questions we shall set out our methodology.

\section{Methodology}

To examine the questions we have posed, we use data from the United Nations Commodity Trade Statistics Database (COMTRADE), ${ }^{9}$ the most comprehensive and detailed database available on trade. Nevertheless, we

9 See [online] http://comtrade.un.org/db. 
recognize that trade statistics can be susceptible to errors and discrepancies, and that the data available in COMTRADE are no exception.

We use the second revision of the Standard International Trade Classification (sITC Rev. 2), 1976, in order to ensure the homogeneity of data for our sample of countries. This classification groups goods under 10 headings using one-digit codes, and then further breaks them down until it identifies a total of 1,924 different products using five-digit codes (United Nations, 1975, p. vii). The more digits we include, the more different products we identify; however, conducting our quantitative analysis at the most detailed level (five digits) may not actually help us to identify new exports that point to diversification in goods. For example, at the five-digit level meat with bones and meat without bones are considered as two different products, whereas for our purposes, we should group them together. Volpe and Milena (2009) used data at the 10-digit level of the Harmonized Commodity Description and Coding System (an alternative to SITC) and their conclusions regarding the ability of tariff reductions to foster export diversification are accordingly overly optimistic as it is arguable whether they are in effect identifying significantly different products at that level of accuracy. We therefore seek to strike a balance between excessive precision and excessive clustering, both of which would have a negative impact on our results. Evenett and Venables (2002) proposed a simple list containing 71 products defined at the two-digit level, but with a minimum threshold of US\$ 50,000 for each product line. In other words, exports of specific goods totalling less than US\$50,000 were not counted and therefore if exports grew from, say, US\$30,000 to US $\$ 500,000$ dollars, that growth was considered to be in the extensive margin. For our research, our product list was defined at the two-digit level using sITC Rev. 2 and we applied a threshold of US $\$ 50,000$ per product. To measure change in the region's trading partners, we used a threshold of US $\$ 500,000$ per country and a minimum of 10 goods. ${ }^{10}$

As to the measurement points in time, we chose the years 1990 and 2008. The first because it preceded the current wave of FTAS and the second because it is the most recent year for which data are available, taking into account the need for data smoothing. To control for

\footnotetext{
$10 \mathrm{We}$, in fact, repeated our analysis at the five-digit level (without a threshold) and, although we are unable to publish these results owing to space limitations, our basic findings were also supported at that level of detail and can therefore be considered robust. The results at a five-digit level can be obtained upon request from the authors.
}

one-off exports either in terms of the type of good or the destination market, we average the data from three points in time. Thus, the figures for 1990 and 2008 are actually the averages for the years 1989, 1990 and 1991 and 2007, 2008 and 2009, respectively.

\begin{tabular}{ll} 
TABLE 2 & $\begin{array}{l}\text { Standard International Trade Classification } \\
\text { 1976 (Rev. 2), one-digit codes }\end{array}$ \\
\hline $\begin{array}{l}\text { SITC Rev. 2 } \\
\text { section headings }\end{array}$ & Description \\
\hline 0 & $\begin{array}{l}\text { Food and live animals, chiefly for food } \\
\text { Beverages and tobacco }\end{array}$ \\
2 & Crude materials, inedible, except fuels \\
3 & Mineral fuels, lubricants and related materials \\
4 & Animal and vegetable oils, fats and waxes \\
5 & $\begin{array}{l}\text { Chemicals and related products not elsewhere } \\
\text { specified } \\
\text { Manufactured goods classified chiefly by } \\
\text { materials }\end{array}$ \\
7 & $\begin{array}{l}\text { Machinery and transport equipment } \\
\text { Miscellaneous manufactured articles } \\
\text { Commodities and transactions not elsewhere } \\
\text { classified }\end{array}$ \\
9 &
\end{tabular}

Source: United Nations Commodity Trade Statistics Database (COMTRADE).

By choosing 2008 for our analysis, we must exclude all the agreements that came into force after that year. The vast majority of FTAS and PTAS were signed before 2006, which leaves us with enough time for their possible effects to be captured by our data.

Interpreting the data from these years poses certain difficulties as the fall of the Iron Curtain led to the creation of several new countries in the early 1990s. The Soviet Union ceased to exist, while new independent States, such as Croatia, were established. In addition, in 1990 there was a decision to separate data on Belgium and Luxembourg in COMTRADE (they had previously been treated as a single entity). As each country has a separate country code, these events artificially led to the gain or loss of trading partners for our selection of Latin American countries, irrespective of their intentions or efforts. Nevertheless, trying to retroactively calculate the GDP of the present-day countries that made up Yugoslavia, Czechoslovakia or the Soviet Union would be a difficult and arbitrary exercise and it would be impossible to trace which products were exported where. Owing to the difficulties caused by the lack of accurate data, we decided to maintain the original country coding. In what 
follows, then, we have to be careful when interpreting the data on changes in trading partners, since both losses and acquisitions are overstated. In our comparative analysis, however, this overvaluation should not affect the essence of our conclusions.

All of the figures we present are in United States dollars at constant 2008 prices in order to control for inflation, which has been considerable in the last 20 years in Latin America, although admittedly less problematic than in prior decades. The 1990 figures are therefore deflated by the official United States price level reported by the World Bank in its World Development Indicators ${ }^{11}$.

All the data were processed using the default routines of the standard statistical package IBM SPSS Statistics, version 19.0.

\section{The quality of Latin American export growth}

In order to quantify export growth we first compare total exports for our sample of Latin American countries in 1990 with 2008 (see table 3). We have three main observations with regard to real export growth. First, all countries, except for the Bolivarian Republic of Venezuela and Uruguay, at least doubled their real export value during the period under consideration. With the exception of the Bolivarian Republic of Venezuela,
Colombia, Paraguay and Uruguay, exports grew at an average annual rate of $7 \%$ or more in all countries, with Mexico and Peru achieving double-digit growth. In other words, at first glance the results of the Latin American economies in terms of export growth are encouraging and, indeed, more than satisfactory when compared with their average annual real GDP growth.

However, the difference between the pace of average export growth and average real GDP growth suggests that the impact of the former on the latter is not proportional. A second conclusion is that there is no significant linear correlation between the number of signed treaties and export growth. At this point, we need to perform a more detailed analysis.

\section{Changes in export markets}

As mentioned above, the quality of growth depends on the ability to export a greater variety of products to more markets (and ideally in a more evenly distributed way). So, in order to break down our figures we need to establish first to what extent the mix of products and countries has changed (if at all). We begin by addressing the latter.

A simple count shows that all the countries in the study, except the Bolivarian Republic of Venezuela, increased the number of their trading partners and are

TABLE 3

Latin America (selected countries): real export growth, 1990 and 2008

(Thousands of United States dollars at constant 2008 prices and percentages)

\begin{tabular}{|c|c|c|c|c|c|c|}
\hline & $\begin{array}{c}\text { Value of exports } \\
1990 \\
\text { (Thousands of } \\
\text { dollars) }\end{array}$ & $\begin{array}{l}\text { Value of exports } \\
2008 \\
\text { (Thousands of } \\
\text { dollars) }\end{array}$ & $\begin{array}{c}\text { Absolute } \\
\text { export growth } \\
\text { (Thousands of } \\
\text { dollars) }\end{array}$ & $\begin{array}{c}\text { Relative } \\
\text { export growth } \\
\text { (Percentages) }\end{array}$ & $\begin{array}{l}\text { Average annual } \\
\text { export growth } \\
\text { (Percentages) }\end{array}$ & $\begin{array}{l}\text { Average annual } \\
\text { real GDP growth } \\
\text { (Percentages) }\end{array}$ \\
\hline Argentina & 18581526 & 60490183 & 41908657 & 226 & 7.2 & 4.0 \\
\hline Bolivia (Plur. State of) & 1448436 & 5669593 & 4221157 & 291 & 8.4 & 3.7 \\
\hline Brazil & 53407971 & 170528685 & 117120714 & 219 & 7.1 & 2.8 \\
\hline Chile & 14075528 & 62408984 & 48333456 & 343 & 9.2 & 5.2 \\
\hline Colombia & 10840779 & 33490067 & 22649288 & 209 & 6.9 & 3.5 \\
\hline Ecuador & 4342018 & 15493913 & 11151895 & 257 & 7.8 & 3.2 \\
\hline Mexico & 41858114 & 264266121 & 222408006 & 531 & 11.4 & 2.8 \\
\hline Paraguay & 1483131 & 3482506 & 1999375 & 135 & 5.1 & 2.5 \\
\hline Peru & 5074031 & 28703686 & 23629654 & 466 & 10.1 & 4.5 \\
\hline Uruguay & 2674770 & 5281651 & 2606881 & 97 & 4.1 & 2.9 \\
\hline Venezuela (Bol. Rep. of) & 25368189 & 46686981 & 21318792 & 84 & 3.7 & 2.9 \\
\hline
\end{tabular}

Source: authors' calculations based on data from the United Nations Commodity Trade Statistics Database (COMTRADE) and World Bank Development Indicators (average annual GDP growth).

11 See [online] http://data.worldbank.org/indicator. 
therefore geographically more diversified than in 1990 (see table 4). We recall that for our purposes a country must receive exports totalling more than the threshold of US\$ 500,000 to be considered a destination market. The case of the Bolivarian Republic of Venezuela is pathological: as a result of its overdependence on oil the country lost 37 markets. Other striking cases include Brazil (the most diversified country), the Plurinational State of Bolivia (the least diversified, although it is improving), Mexico (the least successful at entering into new markets) and Argentina (the most successful).
In short, Latin American goods reached comparatively more markets in 2008 than in 1990, and therefore we could initially be inclined to conclude that exports are geographically more diversified, thus giving hope to the supporters of the FTA-export diversification nexus. But before drawing such a conclusion, we shall consider whether the top five destinations for our sample (in terms of export value) have changed much. To this end, we computed the share of each trading partner in the total exports of each of our Latin American countries (see table 5).

Latin America (selected countries): growth in export destinations, 1990 and 2008

\begin{tabular}{|c|c|c|c|c|c|c|c|}
\hline & \multirow{2}{*}{$\begin{array}{c}\text { Destination } \\
\text { countries, } 1990\end{array}$} & \multicolumn{2}{|c|}{ Destination countries, 2008} & \multicolumn{2}{|c|}{ Markets gained } & \multicolumn{2}{|c|}{ Markets lost } \\
\hline & & Total number & $\begin{array}{c}\text { Percentage } \\
\text { change }\end{array}$ & Total number & $\begin{array}{c}\text { Percentage } \\
\text { change }\end{array}$ & Total number & $\begin{array}{l}\text { Percentage } \\
\text { change }\end{array}$ \\
\hline Argentina & 112 & 160 & 43 & 59 & 53 & 11 & 10 \\
\hline Bolivia (Plur. State of) & 32 & 52 & 63 & 25 & 78 & 5 & 16 \\
\hline Brazil & 156 & 188 & 21 & 51 & 33 & 19 & 12 \\
\hline Chile & 95 & 134 & 41 & 54 & 57 & 15 & 16 \\
\hline Colombia & 82 & 125 & 52 & 52 & 63 & 9 & 11 \\
\hline Ecuador & 59 & 89 & 51 & 39 & 66 & 9 & 15 \\
\hline Mexico & 109 & 147 & 35 & 55 & 50 & 17 & 16 \\
\hline Paraguay & 50 & 77 & 54 & 37 & 74 & 10 & 20 \\
\hline Peru & 84 & 115 & 37 & 39 & 46 & 8 & 10 \\
\hline Uruguay & 74 & 112 & 51 & 49 & 66 & 11 & 15 \\
\hline Venezuela (Bol. Rep. of) & 93 & 67 & -28 & 11 & 12 & 37 & 40 \\
\hline
\end{tabular}

Source: authors' calculations based on data from the United Nations Commodity Trade Statistics Database (COMTRADE).

TABLE 5

Latin America (selected countries): top five export destinations, 1990 and 2008

(Percentages of total exports)

\begin{tabular}{llrlr}
\hline & & & 2008 \\
\hline Argentina & United States & & & 12 \\
& Brazil & Brazil & 19 \\
& Netherlands & 12 & China & 8 \\
& Former Union of Soviet Socialist Republics & 5 & Chile & 7 \\
& (UsSR) & & & 7 \\
& Italy & 4 & Netherlands & 4 \\
\hline Bolivia (Plur. State of) & Argentina & 28 & Brazil & 38 \\
& United States & 20 & Republic of Korea & 9 \\
& United Kingdom & 12 & Argentina & 8 \\
& Belgium-Luxembourg & 8 & United States & 8 \\
& Brazil & 6 & Japan & 5 \\
\hline Brazil & United States & 22 & United States & 13 \\
& Japan & 8 & China & 9 \\
& Netherlands & 7 & Argentina & 9 \\
& Italy & 4 & Netherlands & 5 \\
& Former Federal Republic of Germany & 3 & Germany & 4 \\
\hline
\end{tabular}


Table 5 (concluded)

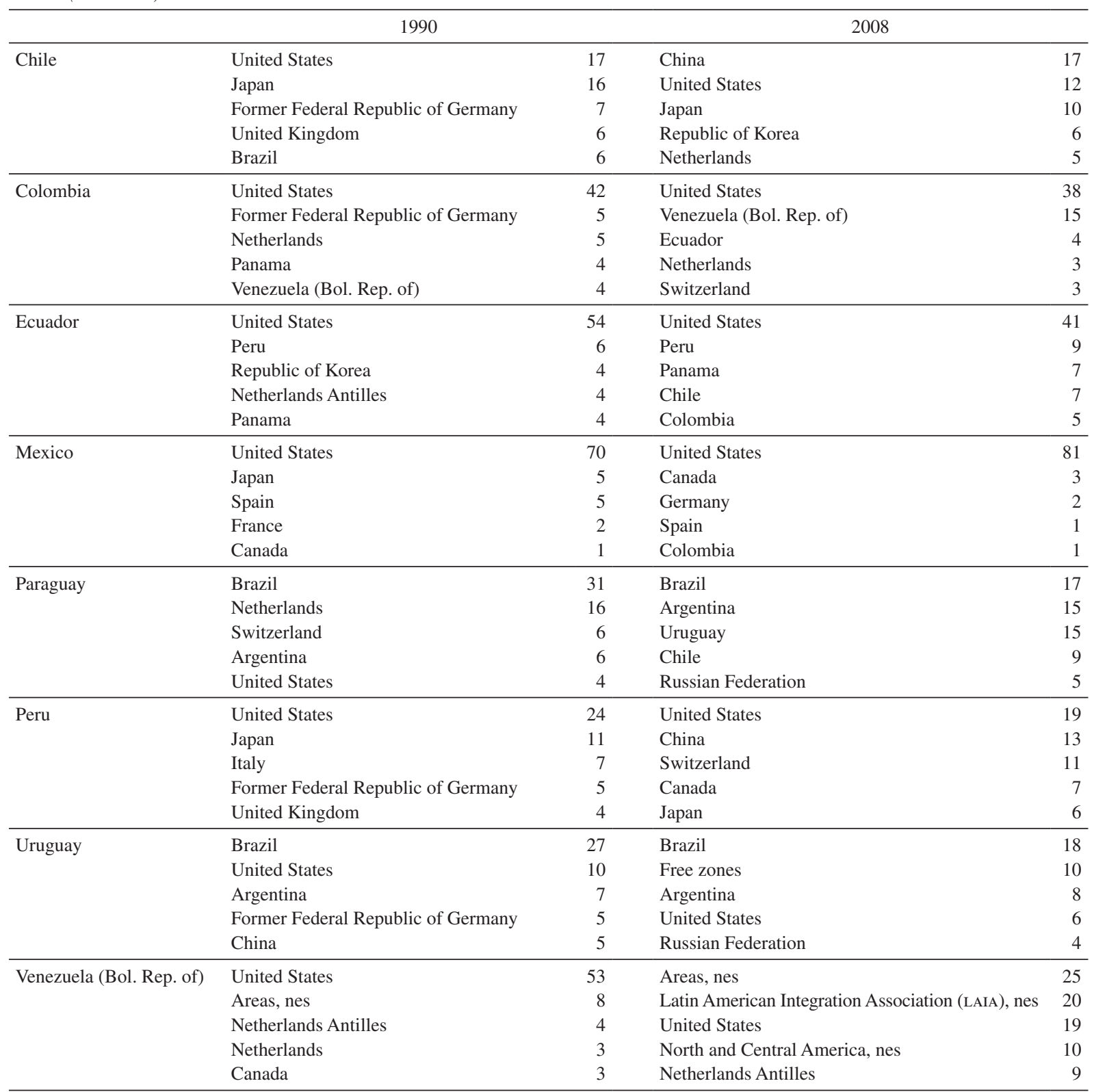

Source: authors' calculations based on data from the United Nations Commodity Trade Statistics Database (COMTRADE).

Abbreviation: nes, not elsewhere specified.

By 2008, the countries of Asia, especially China, had become a crucial trading partner for Latin America, overtaking many European countries. The rise of Brazil within the region is worthy of note. The fastest growing destination countries for Latin American exports were China, Republic of Korea, Brazil and, perhaps surprisingly, the United States. The presence of the United States in this group shows that traditional markets are still some of Latin America's most dynamic trading partners and it would therefore be a mistake to concentrate excessively on new, emerging markets; achieving a balanced mix of destination markets, in order to spread the risk geographically, is more desirable.

This brings us to our second conclusion in this connection: despite the appearance of new markets, the structure of the market shares of each country —and 
therefore their risk-spreading capacity — has not changed dramatically. In our view, diversification is not just a matter of having more trading partners: the export shares of each partner matter as well. The concentration of exports does not seem to have changed much, with the top five destinations continuing to represent similar shares in 2008 as they did in 1990 (this will be verified below). To make matters worse for the supporters of the FTA-export diversification nexus, none of the topperforming partners are new according to our definition. The new markets in the top-five lists for Uruguay and the Bolivarian Republic of Venezuela include one former Soviet republic and artificial groupings owing to a lack of more precise data. Current FTAS are therefore either limited to existing trading partners or incapable of opening up considerable access to new markets.

\section{Changes in exported products}

We now turn to an evaluation of the number of products exported, recalling that for a product to be identified as "new", we apply a threshold of US $\$ 50,000$ per product, with products defined at the two-digit level using SITC Rev. 2. Accordingly, we counted the existing exports for each country in our sample in 1990 and in 2008.

Table 6 shows that, with the exception of Mexico and, curiously enough, Chile, all countries began to export new products during the period under consideration.
The Plurinational State of Bolivia and the Bolivarian Republic of Venezuela stand out in terms of the number of products they stopped exporting between 1990 and 2008 (see the last column of table 6, "products no longer exported"). The net result, however, is that the exports of all countries, except the Bolivarian Republic of Venezuela, are at least equally as diversified in 2008 as in 1990. The situation of the Bolivarian Republic of Venezuela can be explained by its increasing dependence on oil, which currently makes up $95 \%$ of its exports.

When we disaggregate these figures (not shown here for lack of space), we can identify some interesting features. For example, the Plurinational State of Bolivia has stopped exporting rubber, but continues to depend heavily on primary exports, with oil accounting for a growing proportion of its exports. An increasing dependence on commodities is in fact seen across the countries of Latin America. Peru has experienced a major rise in its share of exports under heading number 9 (from $1 \%$ to 19\%); Ecuador saw a fall in its exports under heading 0 and a substantial increase under heading 3; while the share of Paraguay's exports went up under heading 0 and down under heading 2 . These seemingly structural changes simply reflect the substitution of one commodity by another. In the case of Ecuador, for example, the petroleum sector simply outperformed other strong sectors, such as vegetables and fish exports. Paraguay's star commodities were cereals and oil-seeds, and the decrease in the relative share of the

Latin America (selected countries): number of exports, defined at the two-digit level (SITc Rev. 2)

\begin{tabular}{|c|c|c|c|c|c|c|c|}
\hline & \multirow{2}{*}{$\begin{array}{l}\text { Number of products } \\
\text { exported, } 1990\end{array}$} & \multicolumn{2}{|c|}{$\begin{array}{l}\text { Number of products } \\
\text { exported, } 2008\end{array}$} & \multicolumn{2}{|c|}{ New products exported } & \multicolumn{2}{|c|}{ Products no longer exported } \\
\hline & & $\begin{array}{c}\text { Total } \\
\text { number }\end{array}$ & $\begin{array}{c}\text { Percentage } \\
\text { change }\end{array}$ & $\begin{array}{c}\text { Total } \\
\text { number }\end{array}$ & $\begin{array}{c}\text { Percentage } \\
\text { change }\end{array}$ & $\begin{array}{c}\text { Total } \\
\text { number }\end{array}$ & $\begin{array}{l}\text { Percentage } \\
\text { change }\end{array}$ \\
\hline Argentina & 66 & 67 & 2 & 1 & 2 & 0 & 0 \\
\hline Bolivia (Plur. State of) & 40 & 49 & 23 & 15 & 38 & 6 & 15 \\
\hline Brazil & 66 & 67 & 2 & 1 & 2 & 0 & 0 \\
\hline Chile & 67 & 67 & 0 & 0 & 0 & 0 & 0 \\
\hline Colombia & 63 & 67 & 6 & 4 & 6 & 0 & 0 \\
\hline Ecuador & 51 & 61 & 20 & 10 & 20 & 0 & 0 \\
\hline Mexico & 68 & 68 & 0 & 0 & 0 & 0 & 0 \\
\hline Paraguay & 50 & 58 & 16 & 9 & 18 & 1 & 2 \\
\hline Peru & 62 & 66 & 7 & 4 & 6 & 0 & 0 \\
\hline Uruguay & 61 & 64 & 5 & 3 & 5 & 0 & 0 \\
\hline Venezuela (Bol. Rep. of) & 61 & 59 & -3 & 2 & 3 & 4 & 7 \\
\hline
\end{tabular}

Source: authors' calculations based on data from the United Nations Commodity Trade Statistics Database (COMTRADE). Abbreviation: sITC, Standard International Trade Classification. 
textile sector was caused by negative growth. For Peru the change in distribution is attributable in large part to a spectacular rise in gold exports. However promising this performance might be, it is a traditional sector of the Peruvian economy, dating back to pre-colonial times. In other words, despite the impression that a structural change has taken place, the region's export mix remains limited to commodities.

A possible exception is Mexico whose impressive growth in machinery and transport equipment (from $27 \%$ to $53 \%$ ) and in manufactures (from $4 \%$ to $10 \%$ ) suggest that it exported more value added goods. However, this increase is most likely attributable to the maquila sector (see, for example, Kopinak, 1996). The heavy United States presence in the Mexican economy means that there are probably few spillover effects. The supporters of the FTA-export diversification nexus can nevertheless claim that this positive effect, however limited, is caused primarily by Mexico signing the North American Free Trade Agreement (NAFTA). While this may be true, our data show that NAFTA has failed to lead to the export of new goods, and its effects on export diversification and structural change are therefore modest at best.

Finally, even the performance of Latin America's export champion, Chile, falls short. According to our data, its top exports are non-ferrous metals (mainly copper), metalliferous ores (copper again) and vegetables and fruit. Thus even Chile still depends heavily on commodities for its exports.

Table 7 paints a clear picture of this trend by presenting the top three exports in terms of value for each country in our sample.

Latin America (selected countries): top three exports defined at the two-digit level (SITC Rev. 2) in terms of value

(Thousands of United States dollars at constant 2008 prices and percentages of total exports)

\begin{tabular}{|c|c|c|c|c|c|c|}
\hline & \multicolumn{3}{|c|}{1990} & \multicolumn{3}{|c|}{2008} \\
\hline & Product & $\begin{array}{l}\text { Exports } \\
\text { (value) }\end{array}$ & $\begin{array}{l}\text { Percentages of } \\
\text { total exports }\end{array}$ & Product & $\begin{array}{l}\text { Exports } \\
\text { (value) }\end{array}$ & $\begin{array}{l}\text { Percentages of } \\
\text { total exports }\end{array}$ \\
\hline \multirow[t]{3}{*}{ Argentina } & Feeding stuff for animals & 2086154 & 11 & Feeding stuff for animals & 7539836 & 12 \\
\hline & Cereals & 2007346 & 11 & Cereals & 5713809 & 9 \\
\hline & Fixed vegetable oils and fats & 1757710 & 9 & Road vehicles & 5710469 & 9 \\
\hline \multirow[t]{3}{*}{$\begin{array}{l}\text { Bolivia (Plur. } \\
\text { State of) }\end{array}$} & Metalliferous ores & 429963 & 30 & $\begin{array}{l}\text { Gas, natural and } \\
\text { manufactured }\end{array}$ & 2371695 & 42 \\
\hline & $\begin{array}{l}\text { Gas, natural and } \\
\text { manufactured }\end{array}$ & 370254 & 26 & Metalliferous ores & 1354171 & 24 \\
\hline & Non-ferrous metals & 204826 & 14 & Feeding stuff for animals & 297922 & 5 \\
\hline \multirow[t]{2}{*}{ Brazil } & Iron and Steel & 6626288 & 12 & Metalliferous ores & 16696622 & 10 \\
\hline & Coffee & 3227066 & 6 & Meat & 12310916 & 7 \\
\hline \multirow[t]{3}{*}{ Chile } & Non-ferrous metals & 5349014 & 38 & Non-ferrous metals & 22282866 & 36 \\
\hline & Metalliferous ores & 1898034 & 13 & Metalliferous ores & 15034259 & 24 \\
\hline & Vegetables and fruit & 1430838 & 10 & Vegetables and fruit & 4247813 & 7 \\
\hline \multirow[t]{3}{*}{ Colombia } & Petroleum & 2638905 & 24 & Petroleum & 9781528 & 29 \\
\hline & Coffee & 2478690 & 23 & Coal, cokes and briquettes & 4651420 & 14 \\
\hline & Coal, cokes and briquettes & 894728 & 8 & Coffee & 2005732 & 6 \\
\hline \multirow[t]{3}{*}{ Ecuador } & Petroleum & 2033015 & 47 & Petroleum & 8987801 & 58 \\
\hline & Vegetables and fruit & 872661 & 20 & Vegetables and fruit & 1953539 & 13 \\
\hline & $\begin{array}{l}\text { Fish, crustacean and } \\
\text { mollusks }\end{array}$ & 768844 & 18 & $\begin{array}{l}\text { Fish, crustacean and } \\
\text { mollusks }\end{array}$ & 1561592 & 10 \\
\hline Mexico & $\begin{array}{l}\text { Power generating machinery } \\
\text { and equipment }\end{array}$ & 2517816 & 6 & $\begin{array}{l}\text { Telecommunications and } \\
\text { sound equipment }\end{array}$ & 38460315 & 15 \\
\hline
\end{tabular}




\begin{tabular}{|c|c|c|c|c|c|c|}
\hline & \multicolumn{3}{|c|}{1990} & \multicolumn{3}{|c|}{2008} \\
\hline & Product & $\begin{array}{l}\text { Exports } \\
\text { (value) }\end{array}$ & $\begin{array}{l}\text { Percentages of } \\
\text { total exports }\end{array}$ & Product & $\begin{array}{l}\text { Exports } \\
\text { (value) }\end{array}$ & $\begin{array}{l}\text { Percentages of } \\
\text { total exports }\end{array}$ \\
\hline \multirow[t]{3}{*}{ Paraguay } & Textile fibers & 521564 & 35 & Oil seeds & 1150657 & 33 \\
\hline & Oil seeds & 452309 & 30 & Meat & 521811 & 15 \\
\hline & Meat & 156231 & 11 & Feeding stuff for animals & 411909 & 12 \\
\hline \multirow[t]{3}{*}{ Peru } & Non-ferrous metals & 1275859 & 25 & Metalliferous ores & 8143503 & 28 \\
\hline & Metalliferous ores & 963191 & 19 & Gold & 5496655 & 19 \\
\hline & Feeding stuff for animals & 666059 & 13 & Non-ferrous metals & 4215068 & 15 \\
\hline \multirow[t]{3}{*}{ Uruguay } & Textile fibres & 488295 & 18 & Meat & 1129686 & 21 \\
\hline & Meat & 411391 & 15 & Cereals & 723320 & 14 \\
\hline & $\begin{array}{l}\text { Articles of apparel and } \\
\text { clothing accessories }\end{array}$ & 269189 & 10 & $\begin{array}{l}\text { Dairy products and birds' } \\
\text { eggs }\end{array}$ & 375115 & 7 \\
\hline \multirow{3}{*}{$\begin{array}{l}\text { Venezuela } \\
\text { (Bol. Rep. of) }\end{array}$} & Petroleum & 19951725 & 79 & Petroleum & 44028286 & 94 \\
\hline & Non-ferrous metals & 1423300 & 6 & Iron and Steel & 870092 & 2 \\
\hline & Iron and Steel & 855551 & 3 & Non-ferrous metals & 452126 & 1 \\
\hline
\end{tabular}

Source: authors' calculations based on data from the United Nations Commodity Trade Statistics Database (COMTRADE).

Abbreviation: sITC, Standard International Trade Classification.

Based on these data, we conclude, first, that the region has seen little change in its export mix. Second, judging from the shares of the top three exports for each country, the distribution of exports in 2008 is very similar to in 1990. The exports of Latin American economies continue to be heavily concentrated in and dependent on primary commodities.

In sum, our data show that there has been little change in the production mix of these export sectors and the desired increase in value added products has certainly not been seen. Even the two exceptions, Mexico and Argentina, have not been able to create new higher value added goods. Consequently, we do not expect to see any significant growth in the extensive margin, which we will address in the next subsection.

\section{Growth in the extensive and intensive margins}

Let us now turn our attention to the quality of Latin American export growth during the period 1990-2008. The level of diversification can be assessed by quantifying growth in the extensive and intensive margins and computing the relevant concentration indices. We use the definition of extensive and intensive margins presented in Brenton and Newfarmer (2009, p. 112), according to which export growth can take place in relation to either a country's markets or products, which can be either new or existing, giving us four possible combinations.
The expansion of exports of an existing product to an existing market contributes to growth in the intensive margin. Increased exports of a new product to a new market can be classified as export growth in the extensive margin, which we will refer to as type II. The two remaining combinations contain both a new and an existing element. Type I $a$ export growth in the extensive margin involves the export of a new product to an existing market. Lastly, we will refer to an increase in exports of an existing commodity to a new market as type $\mathrm{I} b$ export growth in the extensive margin (see table 8).

The data in table 8 confirm our suspicions, for they indicate that, in general, export growth in Latin America involves the expansion of existing products to existing markets (intensive margin). Even for Latin America's most active FTA signatory, Chile, the intensive margin accounts for $95.9 \%$ of its total export growth. The figure for Mexico is even more extreme: $98.9 \%$ of its total export growth is in the intensive margin. The virtual absence of type II growth in the extensive margin points to the generalized failure of the current Latin American international economic positioning strategy to create new opportunities. In fact, when we analyse the quality of growth broken down according to the 10 sITc Rev. 2 one-digit section headings, we can confirm that the Latin American economies have hardly achieved any extensive growth in the high-technology or higher value added sectors. 
Latin America (selected countries): export growth

in the intensive and extensive margins

(Thousands of United States dollars at constant 2008 prices and percentages)

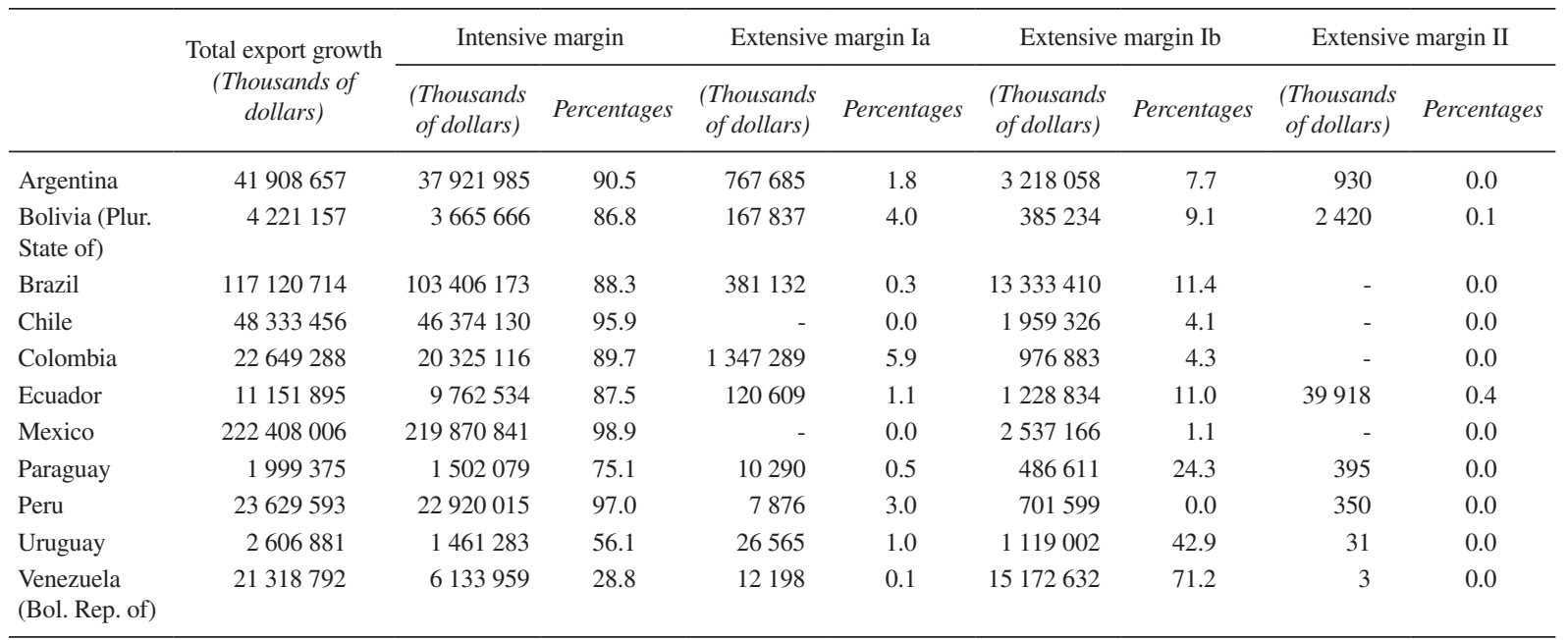

Source: authors' calculations based on data from the United Nations Commodity Trade Statistics Database (COMTRADE).

Nevertheless, there is a small spark of hope for the supporters of the FTA-export diversification nexus. The Latin American economies have fared relatively better in achieving extensive growth in terms of new markets. To what extent FTAs (and trade agreements in general) are responsible for creating new markets will be analysed below. We will also look at how the changes in the shares of the export markets and goods have contributed to the relative diversification or concentration of exports.

\section{Diversification or concentration of exports?}

The diversification of exports can be measured in many ways; we have chosen to use four common concentration indices identified by Samen (2010), namely the Herfindahl index, the Hirschman index, the Ogive index and the entropy index. But, in contrast to the standard practice of computing these indices only for goods, we will also calculate them for countries. This way we will have two values for each concentration index for each country: one for growth in relation to products and one in relation to trading partners. follows:

The Herfindahl index for country $j$ is defined as

$$
H I 1_{j}=\sum_{i=1}^{N}\left[\frac{x_{i}}{X_{j}}\right)^{2}
$$

Where $x_{i}$ is defined as the total exports of product $i$ or as the total exports to country $i$, and $X_{j}$ is defined as the total exports of country $j . N$ is the total number of goods (or countries). The definition of these symbols will be maintained throughout this article.

The Hirschman index for country $j$ is defined as follows:

$$
H I 2_{j}=\sqrt{\sum_{i=1}^{N}\left(\frac{x_{i}}{X_{j}}\right)^{2}}
$$

Basically, the Hirschman index is equal to the root of the Herfindahl index. In both cases, they compare the actual concentration with an evenly distributed export mix of goods (or export markets), and a higher index indicates a greater concentration of exports. In the case of absolute concentration, the index would be equal to one and in the most diversified case it would be close to zero.

The Ogive index for country $j$ is defined as follows:

$$
0 G V_{j}=N \sum_{i=1}^{N}\left(\frac{x_{i}}{X_{j}}-1 / N\right)^{2}
$$

This index measures the deviation from an equal distribution of export shares (in terms of goods or 
countries). $1 / \mathrm{N}$ is considered to be the ideal share of a product (or trading partner) in total exports. When the value approaches zero, it means that the export sector is highly diversified. An index close to one means that it is highly concentrated.

Finally, the entropy index for country $j$ is defined as follows:

$$
E N T_{j}=\sum_{i=1}^{N}\left(\frac{x_{i}}{X_{j}} x \log _{2}\left(\frac{X_{j}}{x_{i}}\right)\right)
$$

In contrast to the other measures, the maximum is attained when all products (or countries) are evenly distributed. Thus, lower values indicate a higher concentration of exports.

The results of these four indices are presented in table 9 . As the results of the four indices are consistent, we will focus our analysis on the Herfindahl index.

We can draw some interesting conclusions from the indices. First, there tends to be a correlation between the indices for products and trading partners, with the only exceptions being Mexico and the Bolivarian Republic for trading partners and products defined at the two-digit level (SITC Rev. 2).

\begin{tabular}{|c|c|c|c|c|c|}
\hline & \multirow{2}{*}{ Index } & \multicolumn{2}{|c|}{ Products } & \multicolumn{2}{|c|}{ Trading partners } \\
\hline & & 1990 & 2008 & 1990 & 2008 \\
\hline \multirow[t]{4}{*}{ Argentina } & HI1 & 0.060 & 0.058 & 0.055 & 0.064 \\
\hline & HI2 & 0.244 & 0.242 & 0.235 & 0.254 \\
\hline & OGV & 2.972 & 2.932 & 5.274 & 7.478 \\
\hline & ENT & 4.632 & 4.736 & 5.001 & 5.045 \\
\hline \multirow[t]{4}{*}{ Bolivia (Plur. State of) } & HI1 & 0.180 & 0.242 & 0.151 & 0.176 \\
\hline & HI2 & 0.425 & 0.492 & 0.388 & 0.419 \\
\hline & OGV & 6.765 & 11.140 & 9.926 & 8.097 \\
\hline & ENT & 3.212 & 2.925 & 3.337 & 3.471 \\
\hline \multirow[t]{4}{*}{ Brazil } & HI1 & 0.046 & 0.044 & 0.073 & 0.047 \\
\hline & HI2 & 0.215 & 0.211 & 0.270 & 0.217 \\
\hline & OGV & 2.076 & 1.991 & 8.768 & 7.076 \\
\hline & ENT & 4.970 & 5.012 & 5.046 & 5.372 \\
\hline \multirow[t]{4}{*}{ Chile } & HI1 & 0.184 & 0.197 & 0.079 & 0.072 \\
\hline & HI2 & 0.429 & 0.443 & 0.280 & 0.268 \\
\hline & OGV & 11.333 & 12.178 & 6.290 & 6.464 \\
\hline & ENT & 3.477 & 3.403 & 4.458 & 4.559 \\
\hline \multirow[t]{4}{*}{ Colombia } & HI1 & 0.133 & 0.119 & 0.192 & 0.175 \\
\hline & HI2 & 0.364 & 0.345 & 0.438 & 0.418 \\
\hline & OGV & 7.434 & 6.970 & 12.828 & 14.741 \\
\hline & ENT & 3.758 & 4.200 & 3.873 & 3.913 \\
\hline \multirow[t]{4}{*}{ Ecuador } & HI1 & 0.300 & 0.365 & 0.303 & 0.193 \\
\hline & HI2 & 0.548 & 0.604 & 0.550 & 0.440 \\
\hline & OGV & 14.628 & 21.384 & 14.201 & 11.981 \\
\hline & ENT & 2.243 & 2.498 & 3.111 & 3.581 \\
\hline \multirow[t]{4}{*}{ Mexico } & HI1 & 0.136 & 0.086 & 0.496 & 0.659 \\
\hline & HI2 & 0.369 & 0.294 & 0.704 & 0.812 \\
\hline & OGV & 8.244 & 4.870 & 38.355 & 66.268 \\
\hline & ENT & 4.130 & 4.297 & 2.317 & 1.654 \\
\hline \multirow[t]{4}{*}{ Paraguay } & HI1 & 0.233 & 0.172 & 0.141 & 0.093 \\
\hline & HI2 & 0.482 & 0.414 & 0.375 & 0.305 \\
\hline & OGV & 10.856 & 9.015 & 8.112 & 5.780 \\
\hline & ENT & 2.817 & 3.276 & 3.762 & 4.288 \\
\hline
\end{tabular}


Table 9 (concluded)

\begin{tabular}{|c|c|c|c|c|c|}
\hline & \multirow{2}{*}{ Index } & \multicolumn{2}{|c|}{ Products } & \multicolumn{2}{|c|}{ Trading partners } \\
\hline & & 1990 & 2008 & 1990 & 2008 \\
\hline \multirow[t]{4}{*}{ Peru } & HI1 & 0.136 & 0.154 & 0.084 & 0.082 \\
\hline & HI2 & 0.369 & 0.392 & 0.290 & 0.287 \\
\hline & OGV & 7.417 & 9.179 & 6.317 & 6.470 \\
\hline & ENT & 3.538 & 3.422 & 4.513 & 4.341 \\
\hline \multirow[t]{4}{*}{ Uruguay } & HI1 & 0.093 & 0.086 & 0.104 & 0.064 \\
\hline & HI2 & 0.304 & 0.294 & 0.323 & 0.254 \\
\hline & OGV & 4.709 & 4.538 & 7.306 & 5.320 \\
\hline & ENT & 4.144 & 4.393 & 4.308 & 4.900 \\
\hline \multirow[t]{4}{*}{ Venezuela (Bol. Rep. of) } & HI1 & 0.624 & 0.890 & 0.292 & 0.164 \\
\hline & HI2 & 0.790 & 0.943 & 0.541 & 0.405 \\
\hline & OGV & 37.169 & 51.654 & 18.323 & 8.677 \\
\hline & ENT & 1.631 & 0.523 & 3.204 & 3.102 \\
\hline
\end{tabular}

Source: authors' calculations based on data from the United Nations Commodity Trade Statistics Database (COMTRADE).

Abbreviations: sITc, Standard International Trade Classification; HI1, Herfindahl index; HI2, Hirschman index; OGV, Ogive index; ENT, entropy index.

of Venezuela, for reasons already mentioned. Second, only four countries succeeded in diversifying both their markets and their exports (Brazil, Colombia, Paraguay and Uruguay), although in general these changes were only minimal. Third, diversification, however small, was achieved to a greater extent in relation to target markets than goods.
Before drawing hasty conclusions, however, we have to acknowledge the sensitivity (with the exception of the Ogive index) of these indices to the number of products or trading partners. To wit, the index favours countries with a small $N$ (ceteris paribus). Therefore it is common to compare these indices for a fixed $N$. The results for the top 10 products and export markets are presented in table 10.

TABLE 10

Latin America (selected countries):Herfindahl index calculated for the top 10 products (two-digit level, SITC Rev. 2) and trading partners

\begin{tabular}{lllll}
\hline & \multicolumn{2}{c}{ Products } & & \multicolumn{2}{c}{ Trading partners } \\
\cline { 2 - 5 } \cline { 3 - 4 } & 1990 & 2008 & 1990 & 2008 \\
\hline Argentina & 0.113 & 0.125 & 0.138 & 0.171 \\
Bolivia (Plur. State of) & 0.230 & 0.290 & 0.181 & 0.233 \\
Brazil & 0.124 & 0.117 & 0.194 & 0.147 \\
Chile & 0.245 & 0.278 & 0.144 & 0.142 \\
Colombia & 0.191 & 0.230 & 0.342 & 0.322 \\
Ecuador & 0.318 & 0.432 & 0.431 & 0.278 \\
Mexico & 0.261 & 0.152 & 0.643 & 0.783 \\
Paraguay & 0.266 & 0.211 & 0.219 & 0.159 \\
Peru & 0.172 & 0.189 & 0.178 & 0.147 \\
Uruguay & 0.146 & 0.163 & 0.193 & 0.149 \\
Venezuela (Bol. Rep. of) & 0.710 & 0.910 & 0.427 & 0.187 \\
\hline
\end{tabular}

Source: authors' calculations based on data from the United Nations Commodity Trade Statistics Database (COMTRADE).

Abbreviation: sITC, Standard International Trade Classification. 
When controlling for the number of exported goods and trading partners, we find that the only two countries that have diversified in both dimensions are Brazil and Paraguay. The export mix of Colombia and Uruguay is relatively small in comparison with the rest of Latin America as their economies are increasingly concentrated in commodities. The fact that they score better on the Herfindhal index than the Plurinational State of Bolivia, which has an even smaller amount of exported goods, is not a contradiction: the top three exports of the Plurinational State of Bolivia represent a higher share than those of Colombia and Uruguay.

Another difference in the values given by the two indices is that, according to the Herfindhal index, Chile is the most diversified in terms of trading partners, while the Ogive index places Chile third, behind Paraguay and Uruguay. The difference is that the top-10 Herfindahl index excludes commodities, whereas the Ogive index does not. What is consistent between the two indices, however, is that Chile has fared better at diversifying its trading partners than the products it exports.

In sum, these concentration indices did not produce any major surprises. The limited structural changes they revealed showed a greater diversification in terms of trading partners than products. This supports our claim that the productive structure of the export sector in Latin American countries has not changed significantly. The absence of an effect does not necessarily mean that FTAS (and trade agreements in general) are ineffective and perhaps the findings would have been bleaker if no FTAS had been signed. However, we believe that this is highly unlikely and will tackle this question in the next subsection.

\section{FTAS and diversification}

The coverage of FTAs is significant: as shown in table 11 , the exports covered by a PTA or FTA have increased since 1990 for all countries except Uruguay.

The expanding coverage of FTAS is hardly surprising, considering that most of these agreements were signed after 1990. Nevertheless, their impact has been astonishing in the cases of Mexico and Chile, with $94 \%$ and $80 \%$, respectively, of their trade with other countries covered by FTAs. At the other extreme, less than $10 \%$ of the total exports of the Bolivarian Republic of Venezuela, Colombia and Ecuador are covered by FTAs.

Table 12 shows whether these FTAs created new markets or merely confirmed existing ties.

Latin America (selected countries): exports covered

and not covered by trade agreements

(Thousands of United States dollars at constant 2008 prices and percentages)

\begin{tabular}{|c|c|c|c|c|c|c|c|c|}
\hline & \multicolumn{4}{|c|}{ Total exports, 1990} & \multicolumn{4}{|c|}{ Total exports, 2008} \\
\hline & \multicolumn{2}{|c|}{ Without agreement } & \multicolumn{2}{|c|}{ With agreement } & \multicolumn{2}{|c|}{ Without agreement } & \multicolumn{2}{|c|}{ With agreement } \\
\hline & $\begin{array}{l}\text { Thousands } \\
\text { of dollars }\end{array}$ & Percentages & $\begin{array}{l}\text { Thousands } \\
\text { of dollars }\end{array}$ & Percentages & $\begin{array}{l}\text { Thousands } \\
\text { of dollars }\end{array}$ & Percentages & $\begin{array}{l}\text { Thousands } \\
\text { of dollars }\end{array}$ & Percentages \\
\hline Argentina & 18582 & 100 & 0 & 0 & 36717272 & 61 & 23772911 & 39 \\
\hline $\begin{array}{l}\text { Bolivia } \\
\text { (Plur. State of) }\end{array}$ & 1448436 & 100 & 0 & 0 & 3032614 & 53 & 2636979 & 47 \\
\hline Brazil & 53407971 & 100 & 0 & 0 & 137078944 & 80 & 33449741 & 20 \\
\hline Chile & 14075528 & 100 & 0 & 0 & 11772471 & 19 & 50636513 & 81 \\
\hline Colombia & 10294937 & 95 & 545841 & 5 & 30498885 & 91 & 2991182 & 9 \\
\hline Ecuador & 4342018 & 100 & 0 & 0 & 14334362 & 93 & 1159551 & 7 \\
\hline Mexico & 41229536 & 98 & 628579 & 2 & 16331152 & 6 & 247934969 & 94 \\
\hline Paraguay & 1483131 & 100 & 0 & 0 & 2294703 & 66 & 1187803 & 34 \\
\hline Peru & 4930197 & 98 & 91303 & 2 & 18980869 & 66 & 9722816 & 34 \\
\hline Uruguay & 1944685 & 73 & 730086 & 27 & 4231930 & 80 & 1049721 & 20 \\
\hline $\begin{array}{l}\text { Venezuela } \\
\text { (Bol. Rep. of) }\end{array}$ & 24680937 & 97 & 687252 & 3 & 44806718 & 96 & 1880264 & 4 \\
\hline
\end{tabular}

Source: authors' calculations based on data from the United Nations Commodity Trade Statistics Database (COMTRADE). 
Latin America (selected countries): exports to trading partners before and after signing free trade agreements, 1990 and 2008

(Thousands of United States dollars at constant 2008 prices and percentages of total exports)

\begin{tabular}{|c|c|c|c|c|c|}
\hline & \multicolumn{2}{|c|}{ Exports in 1990 to future FTA partners } & \multicolumn{2}{|c|}{ Exports in 2008 to FTA partners } & \multirow{2}{*}{$\begin{array}{c}\text { Annual average } \\
\text { growth }\end{array}$} \\
\hline & Thousands of dollars & Percentage of total & Thousands of dollars & Percentage of total & \\
\hline Bolivia (Plur. State of) & 495557 & 34.20 & 2636979 & 46.50 & 10.3 \\
\hline Brazil & 5586579 & 10.50 & 33449741 & 19.60 & 11.1 \\
\hline Chile & 9758851 & 69.30 & 50636513 & 81.10 & 10.2 \\
\hline Colombia & 607489 & 5.60 & 2991182 & 8.90 & 9.8 \\
\hline Ecuador & 178728 & 4.10 & 1159551 & 7.50 & 11.6 \\
\hline Mexico & 37302311 & 89.10 & 247934969 & 93.80 & 11.8 \\
\hline Paraguay & 161372 & 10.90 & 1187803 & 34.10 & 12.5 \\
\hline Peru & 1513771 & 30.10 & 9722816 & 33.90 & 11.6 \\
\hline Uruguay & 344525 & 12.90 & 1049721 & 19.90 & 6.8 \\
\hline
\end{tabular}

Source: authors' calculations based on data from the United Nations Commodity Trade Statistics Database (comTRADE).

The data show that trade with future FTA partners was already relatively substantial in 1990 and their share in total exports rose significantly between 1990 and 2008 for all countries except for the Bolivarian Republic of Venezuela. Average annual growth in exports to FTA partners was higher than the growth seen in exports to all countries (see table 3 ). Given the existing significance of these export destinations for the economies in question, it is difficult to conclude that the trade agreements opened up new markets.

In terms of access to new markets, our data indicate that only six countries began exporting to new countries (according to our threshold) under a trade agreement. Disregarding the Eastern European countries established following the dissolution of the Soviet Union and other artificial changes (such as the separation of data on Belgium and Luxembourg in COMTRADE), Chile gained access to the markets of Bulgaria, Iceland, and Malta; Colombia to Antigua and Barbuda, Belize, Guyana and Saint Kitts and Nevis; Ecuador to Paraguay and Uruguay (which fell short of the threshold in 1990); Mexico to Bulgaria, Iceland and Romania; Paraguay to Ecuador (which fell short of the threshold in 1990); and the Bolivarian Republic of Venezuela to Belize. This list is hardly impressive: the access gained represents less than $1 \%$ of the total exports of these countries in 2008 (hence, these results are economically insignificant). Bulgaria and Romania were new actors in the market economy and it is therefore not clear that an FTA with the
European Union was necessary to gain access to their markets. Ecuador, Paraguay and Uruguay are natural trading partners and trade between them would most probably have expanded even without trade agreements.

All of this suggests that, on the whole, FTAs (and trade agreements in general) have been rather ineffective with regard to fostering access to markets, particularly new markets. Of course, an optimistic interpretation would be that, given this difference in growth rates, there remain dynamic markets available with which the Latin American countries could sign an FTA in order to further boost their performance. While this is possible, in the case of Chile, for example, there are few countries left with which it does not already have an agreement. Furthermore, the most growth was seen in exports to the United States and China - both countries with which Chile already had strong economic ties. From the standpoint of geographical diversification, signing an FTA with either of those two countries would not make much sense.

Another hypothesis is that if FTAs were signed with new trading partners, then type $\mathrm{I} b$ export growth in the intensive margin would occur naturally. Hence, the true potential of FTAs is not really being measured. This is true, in theory, but the list of existing trade partners leaves little room for further expansion. It is questionable whether the reward would be worth the diplomatic effort involved in negotiating agreements with the mainly small countries that remain. In truth, given the existing, endogenously created economic ties, the idea behind signing an FTA 
is not to gain access to new markets, but to diversify an economy's export mix. Of course countries want to see growth in the intensive margin, but this is a short-term gain. The long-term gain is obtained through diversification and FTAs are ineffective to that end.

The data in table 13 show that trade agreements have not been instrumental in fostering the export of new products, except in the cases of Brazil and the Bolivarian Republic of Venezuela. And indeed, no trade agreement has achieved the "purest" form of diversification (new countries and new products).
This ends our preliminary assessment of the relationship between trade agreements, particularly FTAS, and export diversification in terms of both trading partners and products. An analysis of the data has confirmed our main hypothesis: FTAS are a useful and perhaps necessary element of a country's international economic positioning strategy, but if diversification is the objective (as it should be), these agreements must be complemented with other industrial policies. As Osvaldo Rosales, former chief negotiator of Chile, said, an FTA is no guarantee of economic success (Malvasio, 2006).

TABLE 13

Latin America (selected countries): export growth by type of growth and existence of a trade agreement

(Thousands of United States dollars at constant 2008 prices and percentages)

\begin{tabular}{|c|c|c|c|c|c|c|c|c|}
\hline & \multicolumn{4}{|c|}{ Extensive margin $\mathrm{I} a$} & \multicolumn{4}{|c|}{ Extensive margin II } \\
\hline & \multicolumn{2}{|c|}{ Without agreement } & \multicolumn{2}{|c|}{ With agreement } & \multicolumn{2}{|c|}{ Without agreement } & \multicolumn{2}{|c|}{ With agreement } \\
\hline & $\begin{array}{l}\text { Thousands of } \\
\text { US dollars }\end{array}$ & $\%$ & $\begin{array}{c}\text { Thousands of } \\
\text { US dollars }\end{array}$ & $\%$ & $\begin{array}{c}\text { Thousands of } \\
\text { US dollars }\end{array}$ & $\%$ & $\begin{array}{c}\text { Thousands of } \\
\text { US dollars }\end{array}$ & $\%$ \\
\hline Argentina & 767560 & 100 & 125 & 0 & 930 & 100 & $\ldots$ & 0 \\
\hline Bolivia (Plur. State of) & 160608 & 96 & 7229 & 4 & 2420 & 100 & $\ldots$ & 0 \\
\hline Brazil & $\ldots$ & $\ldots$ & 381132 & 100 & $\ldots$ & $\ldots$ & $\ldots$ & $\ldots$ \\
\hline Chile & $\ldots$ & $\ldots$ & $\ldots$ & $\ldots$ & $\ldots$ & $\ldots$ & $\ldots$ & $\ldots$ \\
\hline Colombia & 1333290 & 99 & 13999 & 1 & $\ldots$ & $\ldots$ & $\ldots$ & $\ldots$ \\
\hline Ecuador & 100883 & 84 & 19726 & 16 & 39285 & 98 & 633 & 2 \\
\hline Mexico & $\ldots$ & $\ldots$ & $\ldots$ & $\ldots$ & $\ldots$ & $\ldots$ & $\ldots$ & $\ldots$ \\
\hline Paraguay & 6803 & 66 & 3488 & 34 & 370 & 94 & 25 & 6 \\
\hline Peru & 4954 & 63 & 2922 & 37 & 350 & 100 & $\ldots$ & 0 \\
\hline Uruguay & 954 & 4 & 25611 & 96 & 31 & 100 & $\ldots$ & 0 \\
\hline Venezuela (Bol. Rep. of) & 55 & 0 & 12143 & 100 & 3 & 100 & $\ldots$ & 0 \\
\hline
\end{tabular}

Source: authors' calculations based on data from the United Nations Commodity Trade Statistics Database (COMTRADE).

\section{IV}

\section{Conclusions}

Where does this leave us? Let us sum up the facts. Latin America's international economic integration strategies have focused on the signing of FTAS and PTAS. At first glance, export growth performance has been encouraging, but when we disaggregate the data on growth, several question marks arise. First, although the increase in the number of trading partners has been considerable, and there has undoubtedly been a shift towards Asian countries, the distribution of the shares of the top five export markets has remained almost unchanged. Countries have therefore achieved little overall in terms of spreading their risk. Second, diversification into new exports has been disappointing. In the few cases where countries began to export new products, these were generally commodities that substituted other commodities exports. The export mix of the top three products for each country remained largely unchanged and, therefore, countries did not succeed in bringing about a structural change in 
their economies. Export growth is mainly attributable to growth in the intensive margin. A closer look at the concentration indices shows modest improvements in terms of the number of trading partners, but not in relation to the number of products. Finally, these findings are corroborated by cross-referencing the data on export growth and the existence of FTAs: these agreements have been largely ineffective in fostering export diversification.

FTAS, unsupported by other more comprehensive policies, are indicative of laissez-faire policy approach. These agreements cannot be considered an element of active policy as they simply confirm existing informal practices and do not influence or guide new processes. There has been a disregard for country "fundamentals" (Hausmann, Hwang and Rodrik, 2007) since it is believed that FTAS foster export diversification regardless.

Is Latin America's continuing dependence on primary exports solely explained by FTAs? Certainly not. Often, contingent economic incentives can be counterproductive to export diversification, as is seen most clearly by China's overpowering demand for natural resources and the resulting appreciation of national currencies in Latin America. FTAs would be powerless in the face of such economic forces, even if they did foster export diversification. While this article does not attempt to unravel the causes of export diversification, a broad, active industrial policy would likely have a better chance of mitigating these perverse incentives than the narrower scope of FTAS.

Does this mean that FTAs are superfluous? On the contrary, we acknowledge that FTAs have numerous benefits, just not this one in particular, at least not without the backing of a comprehensive export strategy. An FTA alone will not change the productive structure of an economy. Unlike the former economic advisor to President George H.W. Bush Michael Boskin, who famously said that it did not matter whether an economy made computer chips or potato chips, we hold that the quality of export growth does matter, and that FTAs are not the ideal means to achieving such quality growth. FTAs have proven useful for boosting exports of existing products to existing markets, but do not help countries to branch into new products or markets.

The task ahead, in the realm of policymaking, is therefore to investigate how to promote exports of more value added products and how to achieve a more even distribution (within reason) in terms of the export mix and the shares of trading partners. Policymakers must not fixate on the signing of new FTAS as if the job ended there. This does not mean that they should abandon the notion of free trade, but rather they should focus on how to improve existing strategies by complementing existing and future FTAs with other measures. These agreements will most probably continue to be the main instrument used to promote free trade while the Doha Round remains at an impasse.

This article is but a first foray into this issue. Future research could involve a more thorough, caseby-case analysis of the relationship between FTAs and export diversification and could include other variables. Attention could be focused on the politics of export diversification and look at why the long-term benefits of export diversification have been passed up in favour of short-term gains. Another question is to what extent Latin American businesses and governments really support free trade and, more importantly, why governments and academics alike have defended the FTA-export diversification nexus.

For the time being, it is clear that industrial policy should no longer be a taboo (Rodrik, 2011). If Latin American countries hope to reap the benefits of increased free trade through FTAs, then they must recognize that those benefits are not automatic and that exports also need the guidance of a goal-oriented strategy. Only time will tell whether the Latin American State is an ideal partner to that end.

\section{Bibliography}

Agosín, M. (2006), "Trade and growth: why Asia grows faster than Latin America", IDB Publications, No. 31778, Washington, D.C., Inter-American Development Bank.

Bernama (2007), "At least two more rounds to conclude Malaysia-US FTA", Bernama.com, 12 January [online] http://www.bernama. com.my/bernama/v3/news_lite.php?id=240893.

Bhagwati, J. (1995), "U.S. trade policy: the infatuation with free trade areas", The Dangerous Drift to Preferential Trade Agreements, J. Bhagwati and A. Krueger (eds.), Washington, D.C., American Enterprise Institute for Public Policy Research.

BMI View (2010), "China-ASEAN FTA: Winners and Losers", 6 January [online] http://www.allbusiness.com/economy-economicindicators/economic-conditions-recession/13686748-1.html.
Brenton, P. and R. Newfarmer (2009), "Watching more than the Discovery Channel to diversify exports", Breaking into New Markets: Emerging Lessons for Export Diversification, R. Newfarmer, W. Shaw and P. Walkenhorst (eds.), Washington, D.C., World Bank.

Bulmer-Thomas, V. (2003), The Economic History of Latin America since Independence, Cambridge, Cambridge University Press.

Castañeda, J. (2006), "Latin America's left turn", Foreign Affairs, vol. 85 , No. 3 .

Chang, H.J. (2012), 23 Things They Don't Tell You about Capitalism, New York, Bloomsbury Press.

DIRECON (General Directorate for International Economic Affairs) (2010), Chile: 20 años de negociaciones comerciales, Santiago, Chile. 
Dornbusch, R. and S. Edwards (1991), The Macroeconomics of Populism in Latin America, Chicago, University of Chicago Press.

Edwards, S. (2010), Left Behind: Latin America and the False Promise of Populism, Chicago, University of Chicago Press. (1995), Crisis and Reform in Latin America: from Despair to Hope, Washington, D.C., World Bank.

Evenett, S. and A. Venables (2002), "Export growth in developing countries: market entry and bilateral trade flows", Working Paper, unpublished.

Ffrench-Davis, R., O. Muñoz and G. Palma (1996), "Las economías latinoamericanas, 1950-1990", Historia económica de América Latina, L. Bethell (ed.), Barcelona, Editorial Crítica.

Fishlow, A. and others (1994), Miracle or Design? Lessons from the East Asian Experience, Washington, D.C., Overseas Development Council.

Hausmann, R., J. Hwang and D. Rodrik (2007), "What you export matters", Journal of Economic Growth, vol. 12, No. 1.

Hesse, H. (2008), "Export diversification and economic growth", Working Paper, No. 21, Washington, D.C., World Bank.

Kopinak, K. (1996), Desert Capitalism: Maquiladoras in North America's Western Industrial Corridor, Tucson, University of Arizona Press.

La Primera (2012), "Deben promoverse exportaciones agrícolas excesiva concentración en minerales es un alto riesgo", 16 January [online] http://exportacionesdeperu.blogspot.com/2012/01/ deben-promoverse-exportaciones.html.

Leipziger, D. (2009), "Foreword", Breaking into New Markets: Emerging Lessons for Export Diversification, R. Newfarmer, W. Shaw and P. Walkenhorst (eds.), Washington, D.C., World Bank.

Lynch, David (2010), Trade and Globalization. An Introduction to Regional Trade Agreements, Lanham, Rowman \& Littlefield Publishers.

Malvasio, G. (2006), "No hay TLC que genere beneficios automáticos", El observador, 2 July [online] http://www.eclac.org/comercio/ agenda/0/25950/ElObservador02julio06_ORosalesEntrevista.pdf.

Mejía, J. (2011), Export Diversification and Economic Growth. An Analysis of Colombia's Competitiveness in the European Union's Market, Berlin, Springer Verlag.

Ministry of Foreign Affairs (2011), "Joint statement by President Piñera and President Barack Obama on the occasion of his visit to Santiago, Chile", 21 March [online] http://www.minrel.gob.cl/ prontus_minrel/site/artic/20110321/pags/20110321155528.php.
Rodríguez, F. and D. Rodrik (1999), "Trade policy and economic growth: a skeptic's guide to the cross-national evidence", NBER Working Paper Series, No. 7081, Cambridge, Massachusetts, National Bureau of Economic Research.

Rodrik, D. (2011), The Globalization Paradox: Democracy and the Future of the World Economy, New York, W.W. Norton and Company.

Samen, S. (2010), "A primer on export diversification: key concepts, theoretical underpinnings and empirical evidence", Growth and Crisis Unit, Washington, D.C., World Bank Institute.

Stokes, S. (2001), Mandates and Democracy: Neoliberalism by Surprise in Latin America, New York, Cambridge University Press.

Taylor, L. (1991), "Economic openness. Problems to the century's end", Economic Liberalization: No Panacea. The Experiences of Latin America and Asia, T. Banuri (ed.), Oxford, Oxford University Press.

Thorp, R. (1998), Progress, Poverty and Exclusion: An Economic History of Latin America in the $20^{\text {th }}$ Century, Washington, D.C., Inter-American Development Bank.

Todaro, M. and S. Smith (2006), Economic Development, Boston, Pearson-Addison Wesley.

United Nations (2012), United Nations Commodity Trade Statistics Database (COMTRADE) [online] http://comtrade.un.org/db. (1975), "Standard international trade classification Revision 2", Statistical Series Papers, No. 34, New York.

Van den Berg, H. and J. Lewer (2007), International Trade and Economic Growth, New York, M.E. Sharpe.

Volpe, C. and S. Milena (2009), "Trade policy and export diversification: what should Colombia expect from the FTA with the United States", IDB Working Paper Series, No. 136, Washington, D.C., Inter-American Development Bank.

Williamson, J. (ed.) (1990), Latin American Adjustment: How Much Has Happened?, Washington, D.C., Institute for International Economics.

World Bank (2012), World Development Indicators [online] http:// dat.worldbank.org/indicator.

Yergin, D. and J. Stanislaw (1998), The Commanding Heights. The Battle for the World Economy, New York, Simon \& Schuster. 